\title{
Internett som springbrett - veien tilbake til livet
}

\author{
Å blottlegge en psykisk lidelse på \\ internett kan være risikabelt. Men \\ er skammen over å være syk så \\ hemmende at livet står på pause, \\ kan blogging være et verktøy \\ i tilfriskningsprosessen.
}

Etter år med sult, fortvilelse og alt det destruktive en spiseforstyrrelse ellers medfører, fikk jeg diagnosen anoreksi. Det verste var ikke at jeg fikk påvist beinskjørhet, mulig infertilitet og en slags realitetssjekk - hvor ble det egentlig av alle disse årene? Nei, det verste var at jeg måtte gi opp studiene for tredje gang - og med det alt håp om noensinne å bli et verdifullt og respektert menneske.

Jeg fikk behandling, godtok gradvis diagnosen, og innså, med fortvilelse, alt jeg hadde mistet - vennskap, muligheter, selvrespekt. Tanken på at de som ikke forsto, skulle hviske og tiske om at jeg var en overfladisk idiot som hadde kastet vekk et helt tiår av livet på en slankekur, var så uutholdelig at jeg mer eller mindre isolerte meg fra omverdenen. Og voktet diagnosen som en mørk hemmelighet.

Det kom til et punkt da jeg brukte mer tid og energi på å skjule at jeg var syk enn på å jobbe for å bli frisk. Skammen var så hemmende at den måtte utfordres, og fordi den sosiale angsten fremdeles var sterk, gikk jeg veien om tastaturet for å forklare mine nærmeste hvorfor jeg i flere år trakk meg unna alt fra julefeiringer til fors $\varnothing$ k på klemmer. Fokus var klart - jeg skulle være ærlig om den tiden ingen slapp innpå meg, jeg skulle stikke hull på noen av de misforståelsene for- bundet med anoreksi, og jeg skulle bli frisk.

Blogging var en kontrollert form for eksponering - jeg delte ikke mer enn jeg var komfortabel med, og fordi det selvfølgelig var valgfritt å fordype seg i min hverdag. følte jeg ikke at jeg «presset meg på» dem som ikke følte behov for å involvere seg.

Jeg var heldig. For familie og venner orket faktisk å lese om sult og ambivalens, de tok seg tid til å forstå hvor sterkt jeg $\emptyset n s k e t$ å bli frisk, og hvorfor prosessen var mer komplisert enn «bare å spise». Erlige blogginnlegg la grunnlag for «ekte» samtaler, oppklaring av såre misforståelser, tilgivelse og - endelig - veldig lange klemmer

At andre med spiseforstyrrelser leste og kjente seg igjen, var en enorm bonus. Det var nesten magisk å kommunisere med noen som faktisk forsto. Noen som hadde kjent - både på kropp og sinn - hvordan det er å leve med et helvetes indre jag, behovet for å vrenge av seg sin egen kropp, troen på at alt blir bra bare man blir enda tynnere, bare man jobber enda hardere - at indre verdier kommer som en automatisk konsekvens av ytre prestasjoner.

Jo flere som skrev akkurat sånn er det for meg også, desto mer slapp skammen taket - for hvorfor skal man skamme seg over det som er symptomer på en sykdom? Jeg godtok at jeg aldri valgte å få anoreksi. og at jeg heller ikke var diagnosen min.

Vi utvekslet erfaringer, og temaet var, naturlig nok, nesten utelukkende spiseforstyrrelser. Etter ensomme år var det nettopp denne typen forståelse og tilh $\varnothing$ righet jeg trengte. Men bare for en periode. For enda så verdifulle, og det er de virkelig, vennskap jeg har stiftet online, trengte jeg å gjenoppdage viktigheten av mennesker, nærhet, interaksjon som ikke involverer tastatur - le og snakke om fine ting over varm kakao og boller. Jeg trengte bevisene på at jeg ikke bare var syk. At det fantes mye friskt i meg også.

Og etter hvert som jeg fant tilbake til disse stundene, mistet bloggen sin funksjon.

Kanskje kan man si at det som i begynnelsen reddet meg - gjenkjennelse og samhold - plutselig virket mot sin hensikt. Det nyttet ikke å se fremover samtidig som jeg dvelte ved fortiden. Jeg kjenner flere bloggere som sier de føler seg «fanget». De føler et sterkt fellesskap til andre som er syke, et fellesskap de kanskje vil miste dersom de blir bedre og løsriver seg.

Jeg er takknemlig for at jeg har hatt mennesker rundt meg som har dratt meg vekk fra tastaturet. Skulle jeg fortsatt å fordype meg i andres opp- og nedturer, ville jeg holdt liv i egen sykdom på et tidspunkt da det viktigste jeg gjorde var å skape en identitet separat fra spiseforstyrrelsen.

Jeg er heldig. For meg fungerte bloggen som et springbrett, en trygg avsats mellom isolasjon og et sosialt liv. Akkurat som behandlingstimer og kostlister var $n \varnothing d-$ vendige en periode, er skjerm og tastatur krykker jeg har lagt fra meg. Nå lever jeg i verden. Uten den universitetsgraden som skulle gi meg verdi, uten en diagnose, egentlig uten andre merkelapper å gjemme meg bak enn «meg». Jeg har ikke lenger noe å skjule. Men heller ikke behov for å blogge om det som nå ligger bak meg.

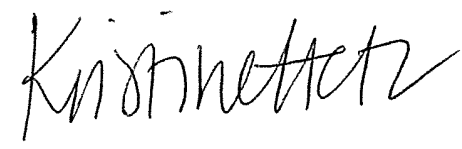

